\title{
The Cystic Fibrosis Transmembrane Regulator (CFTR) in the Kidney*
}

\author{
MARCELO M. MORALES ${ }^{1}$, DORIS FALKENSTEIN ${ }^{2}$ and ANÍBAL GIL LOPES ${ }^{1}$ \\ ${ }^{1}$ Instituto de Biofísica Carlos Chagas Filho \\ Universidade Federal do Rio de Janeiro, CCS - Bloco G 21949-900 - Rio de Janeiro, RJ, Brazil \\ ${ }^{2}$ Instituto de Biologia, Universidade Federal do Rio de Janeiro, Rio de Janeiro, Brazil. \\ Manuscript received on May 11, 2000; accepted for publication on May 17, 2000; \\ contributed by ANíBAL GIL Lopes**
}

\begin{abstract}
The cystic fibrosis transmembrane regulator (CFTR) is a $\mathrm{Cl}^{-}$channel. Mutations of this transporter lead to a defect of chloride secretion by epithelial cells causing the Cystic Fibrosis disease (CF). In spite of the high expression of CFTR in the kidney, patients with CF do not show major renal dysfunction, but it is known that both the urinary excretion of drugs and the renal capacity to concentrate and dilute urine is deficient. CFTR mRNA is expressed in all nephron segments and its protein is involved with chloride secretion in the distal tubule, and the principal cells of the cortical (CCD) and medullary (IMCD) collecting ducts. Several studies have demonstrated that CFTR does not only transport $\mathrm{Cl}^{-}$but also secretes ATP and, thus, controls other conductances such as $\mathrm{Na}^{+}(\mathrm{ENaC})$ and $\mathrm{K}^{+}$(ROMK2) channels, especially in CCD. In the polycystic kidney the secretion of chloride through CFTR contributes to the cyst enlargement.

This review is focused on the role of CFTR in the kidney and the implications of extracellular volume regulators, such as hormones, on its function and expression.
\end{abstract}

Key words: CFTR, kidney, nephron, chloride channel.

\section{INTRODUCTION}

In mammalians, the kidneys are responsible for the maintenance of the extracellular sodium chloride $(\mathrm{NaCl})$ concentration that regulate the extracellular fluid volume (ECFV) and blood pressure. Sodium and chloride are reabsorbed along the nephron, reaching over $99 \%$ of the filtered load under low salt diets. Chloride, the predominant anion in the glomerular ultrafiltrate, is reabsorbed along the nephron either by trans or paracellular pathways (Berry \& Rector 1991). Transcellular transport of

This paper is dedicated to the memory of Prof. Carlos Chagas Filho as a sign of love and friendship.

* Invited paper

** Member of the Academia Brasileira de Ciências

Correspondence to: Aníbal Gil Lopes

E-mail: agilopes@biof.urfj.br
$\mathrm{Cl}^{-}$involves several membrane proteins including the channels.

Numerous chloride channels have been discovered in a variety of animal and plant cells and their modulation and involvement in physiological processes are widely described in the literature. Some of these channels have been cloned and mutations in their genes are associated with genetic diseases (Jentsch 1994, Lehmann-Horn \& Jurkat-Rott 1999, Rojas 1996 \& Sasaki et al. 1994). One of these diseases is cystic fibrosis (CF), a common lethal autosomal recessive disorder, caused by mutations in the cystic fibrosis transmembrane conductance regulator (CFTR) gene, which encodes a multifunctional integral membrane protein expressed in a variety of epithelia, including the renal tubules (Rior- 


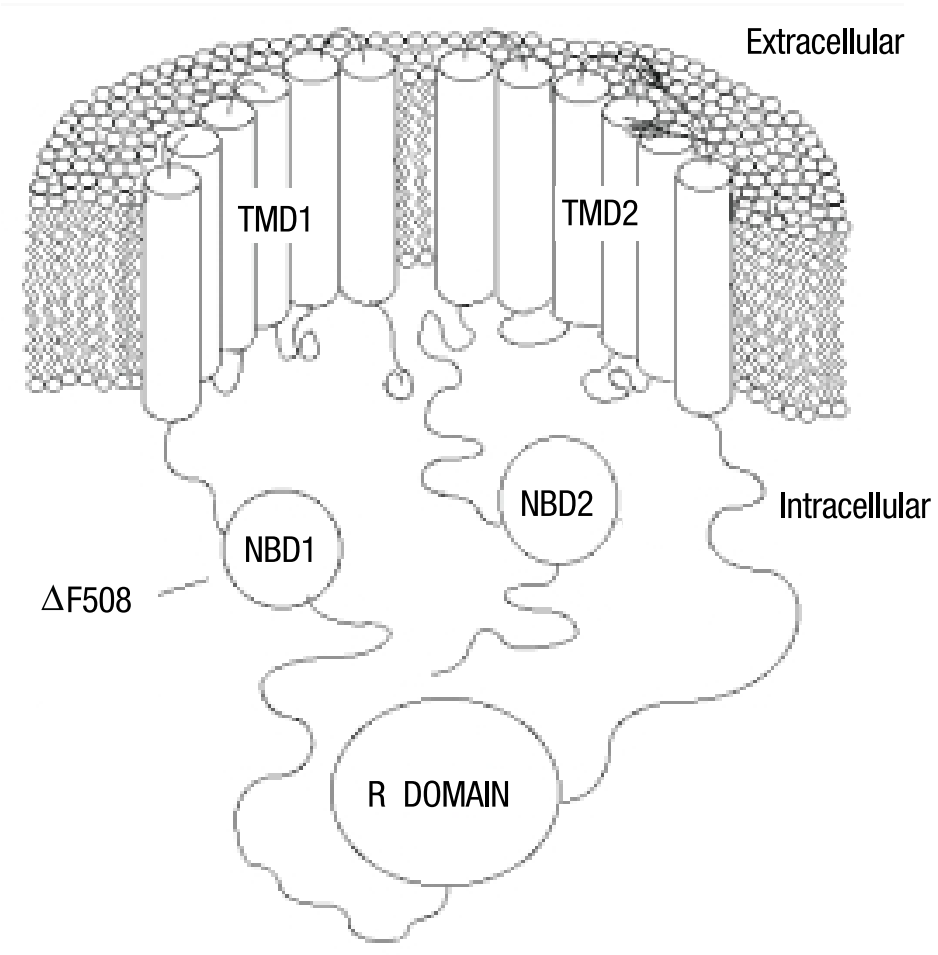

Fig. 1 - Predicted two-dimensional structure of the CFTR protein. The CFTR domains shown are: TMD1 and TMD2-transmembrane-spanning domains 1 and 2, respectively; R domain-regulatory domain; NBD1 and NBD2nucleotide-binding domains 1 and 2, respectively. The most common mutation, $\triangle \mathrm{F} 508$, is found in NBD1. Figure modified from Ref. Collins et al. (1990).

dan 1993 \& Rommens et al. 1989). The CFTR gene, identified in the q21-31 region of chromosome 7 (Riordan et al. 1989), encodes a protein of $165-\mathrm{kD}$ containing 1480 amino acids. CFTR is a member of the ATP binding cassette family (ABC) of integral membrane proteins composed of two transmembrane domains (TMDs) and two nucleotide binding domains (NBDs), separated by a larger regulatory domain $(\mathrm{R})$ containing multiple phosphorylation sites (Riordan 1993, Foskett 1998) (Figure 1). CFTR is a 3'5'-cyclic monophosphate, (cAMP)-activated $\mathrm{Cl}^{-}$channel that modulates a series of intracellular functions by a complex process involving both phosphorilation by 3'5'-cAMP -dependent protein kinase A (PKA) and the inter- actions of ATP with the nucleotide-binding domain (Anderson \& Welsh 1992 \& Morales et al. 1999). Besides the chloride transport function, CFTR plays an important role in intracellular vesicular acidification (Barasch et al. 1991), protein processing and traffic (Morris \& Frizzell 1994), secretion of ATP (Winter et al. 1994) and control of the epithelium sodium channel $(\mathrm{ENaC})$, the renal secretory $\mathrm{K}^{+}$channel (ROMK-2) and the outwardly rectifying chloride channel (ORCC) (Ismailov et al. 1996, McNicholas et al. 1996, Sttuts et al. 1995 $\&$ Schwiebert et al. 1995). The CFTR has a voltage dependent low-conductance for chloride ( $9 \mathrm{pS})$, and is found mainly on the apical membrane of secretory as well as absorptive epithelia (Berger et al. 1991). 
In cystic fibrosis, the $\mathrm{Cl}^{-}$channel function of CFTR is defective and more than 600 different mutations in the gene have been described, the $\Delta \mathrm{F} 508$ mutation being the most common (Tsui \& Buchwald 1991). Cystic fibrosis is characterized by accumulation of thick mucus in the airway epithelia and in pancreatic and sweat ducts. These disturbances usually result in pancreatic insufficiency, increase in sweat $\mathrm{Cl}^{-}$concentration, male infertility, intestinal and airway obstructions (Davies et al. 1996). The airways manifestations are the main cause of $\mathrm{CF}$ patient mortality. Secretory cells from the airways epithelia present a defective chloride ion transport through the apical membrane, which results in $\mathrm{Na}^{+}$ and water hyperabsorption, thickening of the mucus and dehydration of the airways (Rojas 1996, Riordan 1993, Davies et al. 1996). Mutations in CFTR impair mucociliary clearance in the lung, which facilitates bacterial infection that results in a cycle of inflammation, tissue damage and finally lung insufficiency (Boat et al. 1989).

In spite of the injury in several organs, patients with cystic fibrosis do not develop major renal dysfunction although they have reduced renal excretion of $\mathrm{NaCl}$ and decreased capacity to dilute and concentrate urine (Donckerwolcke et al. 1992, Stenvinkle et al. 1991). These patients also have an enhanced excretion of penicillin and aminoglicosides in urine (Bates et al. 1997, Strandvik et al. 1989). The impaired salt reabsorption by the kidney could be related to changes in the extracellular fluid volume caused by excessive losses of $\mathrm{NaCl}$ in sweat and feces. However, decreased $\mathrm{NaCl}$ renal excretion might also result from a primary defect in renal function caused by mutations in CFTR.

\section{CFTR AND KIDNEY}

Several studies have demonstrated the presence of CFTR in the kidney, and its mRNA has been detected in all nephron segments by reverse transcription PCR (Riordan et al. 1989, Morales et al. 1996). CFTR was detected in proximal tubule, thin limbs of Henle's loop, and luminal membrane of distal tubule, cortical collecting duct, and the inner medullary collecting duct by immunocytochemistry (Crawford et al. 1991). Patch-clamp analysis has also confirmed its presence in proximal and distal tubules and in cortical and inner medullary collecting ducts (Husted et al. 1995, Letz \& Korbmacher 1997, Stanton 1989, Segal et al. 1993). CFTR is highly expressed during the early stages of kidney development. At gestational age of 12 weeks kidney CFTR is confined to the apical membrane of the ureteric bud derived collecting tubule, and its presence in proximal tubule cytoplasma is first seen at 16 weeks of gestation (Devuyst et al. 1996).

\section{CFTR in Proximal Tubule}

Although immunolocalization studies indicate an apical expression of CFTR in the proximal tubules (Crawford et al. 1991), patch clamp studies localize its activity at the basolateral membrane (Segal et al. 1993). The function of CFTR in proximal tubules is uncertain because the reabsorption of $\mathrm{NaCl}$ in this segment of the nephron is increased in $\mathrm{CF}$, rather than decreased as would be expected if CFTR mediates $\mathrm{Cl}^{-}$absorption (Bates et al. 1997, Stenvinkle et al. 1991). The increase in CF kidney $\mathrm{Cl}^{-}$ reabsorption could be associated with the reduced extracellular volume fluid or with a reduced $\mathrm{NaCl}$ reabsorption in the thick ascending limb of Henle and distal tubule, both found in CF (Donckerwolcke et al. 1992, Strandvik et al. 1989).

On the other side, in CF the defective CFTR channel causes an increase in penicillin and aminoglicosides excretion in the proximal tubule. One hypothesis for this phenotype is that the abnormal CFTR decreases $\mathrm{Cl}^{-}$reabsorption, which increases $\mathrm{Cl}^{-}$in the tubular lumen. This $\mathrm{Cl}^{-}$will move into the cell in exchange for those drugs, which increase their clearance (Woodland et al. 1998).

\section{CFTR in Henle's Loop and Distal Nephron SEgMENTS}

The mRNA for CFTR was found in the thin ascending limbs of Henle's loop, but no protein was indentified in this nephron segment by immunolocalization 
or patch clamp studies (Crawford et al. 1991, Devuyst et al. 1996). The CFTR protein has not been, detected in the thick ascending limbs of Henle's loop by immunocitochemistry, although in patch clamp studies a $\mathrm{Cl}^{-}$channel with a low conductance $(9$ $\mathrm{pS}$ ), dependent of ATP and $\mathrm{Mg}^{++}$, was found in the basolateral membrane (Berger et al. 1991). This channel was denominated pseudo CFTR, since it is still functional in CFTR knockout mice (Marvao et al. 1998).

Distal convoluted tubule CFTR was detected by immunolocalization and patch clamp studies in the apical membrane. Probably $\mathrm{Cl}^{-}$is secreted into the luminal fluid through CFTR in response to the electrochemical gradient generated by the $\mathrm{Na} / \mathrm{Cl}$ cotransporter. CFTR in this segment may also facilitate $\mathrm{HCO}_{3}^{-}$secretion by mediating the recycling of $\mathrm{Cl}^{-}$through the $\mathrm{Cl}^{-} / \mathrm{HCO}_{3}^{-}$exchanger in the apical membrane (Tauc et al. 1996, Rubera et al. 1999). CFTR protein was not found in the connecting tubule, in the $\alpha$ and $\beta$ intercalated cells of collecting ducts or in the outer medullary collecting duct (OMCD) (Crawford et al. 1991, Todd-Turla et al. 1996).

\section{CFTR in COLlecting Ducts}

In cortical collecting ducts (CCD) the CFTR protein was only identified in the apical membrane of the principal cells. There are experimental evidences that $\mathrm{Cl}^{-}$absorption in this nephron segment is through the paracellular pathway following the electrochemical gradient (Koeppen \& Stanton 1992). However, depending of the electrochemical driving force for $\mathrm{Cl}^{-}$movement across the apical membrane CFTR channel, this ion could either be absorbed or secreted (Ling et al. 1994). This $\mathrm{Cl}^{-}$movement is dependent on $\mathrm{Na}^{+}$absorption through the $\mathrm{ENaC}$ channel and may be controlled by hormones like aldosterone and arginine-vasopressin (Duong Van Huyen et al. 1998).

In the inner medullary collecting duct (IMCD) CFTR plays an intriguing role. The CFTR channel is expressed at the apical membrane in this nephron segment, but alternative splice form of this molecule, the TNR-CFTR, was also found (Morales et al. 1996). Electrophysiological studies support the view that $\mathrm{Cl}^{-}$secretion through the CFTR follows the electrochemical driving force across the apical membrane (Kizer et al. 1995, Husted et al. 1995). The $\mathrm{Cl}^{-}$secretion occurs by a two step process, first involving the uptake of $\mathrm{Cl}^{-}$across the basolateral membrane by $\mathrm{Cl}^{-} / \mathrm{HCO}_{3}^{-}$exchange and $\mathrm{Na}^{+} / \mathrm{K}^{+} / 2 \mathrm{Cl}^{-}$cotransport and, then, the efflux of $\mathrm{Cl}^{-}$across the apical membrane through CFTR channel (Letz \& Korbmacher 1997, Moyer et al. 1995, Kizer et al. 1995, Rocha \& Kudo 1990). Arginine vasopressin (AVP) stimulates $\mathrm{Cl}^{-}$secretion in IMCD by increasing 3' 5' -cAMP which activates protein kinase $\mathrm{A}$ (PKA) which in turn activates CFTR channel (Moyer et al. 1995). The role of AVP on $\mathrm{Cl}^{-}$secretion may be related to the fact that $\mathrm{Na}^{+}$ secretion follows that of $\mathrm{Cl}^{-}$, inducing natriuresis and chloruresis to maintain a normal plasma osmolality during dehydration, as observed in vivo in rats (Luke 1973).

\section{TNR-CFTR, THE RENAL Splice Variant of CFTR}

TNR-CFTR, a splice variant isoform of CFTR gene is associated with specific small endosomal populations highly expressed in the renal medulla (Morales et al. 1996). Functional studies with TNR-CFTR, expressed in Xenopus oocytes or mammalian cells, showed cAMP-dependent single chloride channel properties like those of the wild type CFTR, but with lower efficiency (Morales et al. 1996). In medullary collecting ducts the TNR-CFTR protein and mRNA expression is present during embrionic life, increasing during fetal kidney development and reaching the highest level at birth (Devuyst et al. 1996). The specific function of the TNR-CFTR is not clear and does not seem to be related to chloride secretion. Because it is found in abundance in intracellular vesicles in the cytoplasmic compartment, it may be involved in vesicular trafficking.

\section{CFTR and Polycystic Kidney Disease (PKD)}

CFTR expression and chloride channel function is normal in polycystic kidney disease (PKD), an au- 
tosomal dominant genetic disease (Hanaoka et al. 1996, Sullivan et al. 1998). This renal disorder is characterized by the presence of multiple epithelial cyst with epithelial cell proliferation and apical fluid secretion. The cyst enlargement in PKD kidney is thought to involve inappropriate polarized secretion of sodium ions into the tubule lumen due to the mispolarization of the $\left(\mathrm{Na}^{+}+\mathrm{K}^{+}\right)$-ATPase pump in the cyst apical membrane (Wilson 1997). $\mathrm{Na}^{+}$and $\mathrm{Cl}^{-}$contents in cyst fluid are abnormally high, and addition of cAMP to PKD cyst epithelia in culture increases fluid secretion and ATP release into the cyst fluid. These findings could be due to the CFTR, since it is well known that this channel transports both $\mathrm{Cl}^{-}$and ATP (Sullivan et al. 1998) and suggest the involvement of CFTR in PKD cysts fluid secretion and enlargement.

\section{CFTR AND OTHER CONDUCTANCES}

Chloride transport by CFTR in renal epithelia represents a high-energy expenditure, since this channel requires ATP hydrolysis (Winter et al. 1994) and its conductance is too low $(9 \mathrm{pS})$ to produce fast absorptive or secretive fluxes. One possible role for CFTR in the kidney is the activation or inhibition of other channels like ORRC, ENaC and ROMK2 (Ismailov et al. 1996, Wang 1999, Schwiebert et al. 1995, Morris 1999). It has also been shown that argininevasopressin (AVP) produces an increase of chloride secretion due to transcriptional enhancement in the expression of CFTR and other transporters in rat cortical collecting ducts cells (Djelidi et al. 1999).

Recent studies from our group showed that in homozygous Brattleboro rats, a strain of LongEvans rats carrying an autosomal recessive mutation that results in a deficiency of arginine-vasopressin (AVP) secretion in the plasma, the expression of CFTR mRNA was low in the renal cortex and medulla but returned to normal after AVP reposition. The mRNA of CFTR was increased in the medulla of dehydrated Wistar rats and no variation was observed in the cortex. The modulation of CFTR by the main hormone involved in the regulation of body fluid osmolality suggests that this chloride channel play a role in extracellular volume regulation (Morales M M et al. submitted).

\section{CONCLUSION}

The studies reviewed here show the importance of the CFTR channel in the kidney. Besides its function in chloride transport, CFTR modulates different epithelial conductances, such as channels for sodium (ENaCs), potassium (ROMK2) and chloride (OR$\mathrm{CCs})$, probably by mediating ATP transport. Althoug very well studied in other organs, the function of CFTR is not fully understood in the kidney and further studies are crucial to understand its role in renal physiology.

\section{ACKNOWLEDGEMENTS}

The authors would like to thank Dr. Doris Rosenthal for critically reviewing the manuscript.

The present work was supported by grants from Programa de Apoio ao Desenvolvimento Científico e Tecnológico (PADCT III), Fundação José Bonifácio (FUJB), Fundação Carlos Chagas Filho de Amparo à Pesquisa do Estado do Rio de Janeiro (FAPERJ), Fundação de Amparo à Pesquisa do Estado de São Paulo (FAPESP) and Financiadora de Estudos e Projetos (FINEP).

\section{REFERENCES}

ANDERSON MP \& Welsh MJ. 1992. Regulation by ATP and ADP of CFTR chloride channels that contain mutant nucleotide-binding domains. Science Wash. DC 257: 1701-1704.

Barasch J, Kiss B, Prince A, Saiman L, Gruenert D \& Awqati Q. 1991. Defective acidification of intracellular organelles in cystic fibrosis. Nature 352: 70-73.

Bates CM, Baum M \& Quigley R. 1997. Cystic fibrosis presenting with hypokalemia and metabolic alkalosis in a previously healthy adolescent. JAm Soc Nephrol 8: $352-356$

Berger HA, Anderson MP, Gregory RJ, Thompson S, Howard PW, Maurer RA, Mulligan R, SMith 
AE \& Welsh MJ. 1991. Identification and regulation of the cystic fibrosis transmembrane regulatorgenerated chloride channel. J Clin Invest 88: $1422-$ 1431.

Berry CA \& Rector FCJ. 1991. Renal transport of glucose, amino acids, sodium, chloride and water. In "The Kidney" (B.M. Brenner \& FCJ ReCTOR, eds.), 4th ed., pp. 245-282. Saunders, Philadelphia.

Boat TF, Welsh MJ \& Beaudet AL. 1989. Cystic Fibrosis. In "The metabolic basis of inherited disease" (CR Scriver, AL Beaudet, WS Sly \& D Valle, Eds.), pp 2649-2680, McGraw-Hill, New York.

Collins FS, Riordan JR \& Tsui L-C. 1990. The cystic fibrosis gene: isolation and significance. Hospital Pratice 25: 47-57.

Crawford I, Maloney PC, Zeitlin PL, Guggino WB, Hyde SC, Turley H, Gatter KC, Harris A \& HigGINS CF. 1991. Immunocytochemical localization of the cystic fibrosis gene product CFTR. Proc Natl Acad Sci USA 88: 9262-9266.

Davis PB, Drumm M \& Konstan MW. 1996) Cystic fibrosis. Am J Respir Crit Care Med 154: 12291256.

Devuyst O, Burrow CR, Schwiebert EM, Guggino WB \& Wilson PD. 1996. Developmental regulation of CFTR expression during human nephrogenesis. Am J Physiol Renal Physiol 271: F723-735.

Djelidi S, Fay M, Cluzeaud F, Thomas-Soumarmon A, Bonvalet JP, Farman N \& Blot-Chabaud M. 1999. Vasopressin stimulates long-term net chloride secretion in cortical collecting duct cells. FEBS Lett 460(3): 533-538.

Donckerwolcke RA, Van Diemen-Steenvoorde R, Van Der Laag J, Koomans HA \& Boer WH. 1992. Impaired diluting segment chloride reabsorption in patients with cystic fibrosis. Child Nephrol Urol 12: 186-191.

Duong Van Huyen J, Bens M \& Vandewalle A. 1998. Differential effects of aldosterone and vasopressin on chloride fluxes in trans-immortalized mouse cortical collecting duct cells. J Membr Biol 164(1): 79-90.

Foskett JK. 1998. ClC and CFTR chloride channel gating. Annu Rev Physiol 60: 689-717.

Hanaoka K, Devuyst O, Schwiebert E, Wilson PD \& GugGino W. 1996. A role for CFTR in human autosomal dominant polycystic kidney disease. Am J Physiol Cell Physiol 270: C389-C399.

Husted RF, Volk KA, Sigmund RD \& Strokes JB. 1995. Anion secretion by the innner medullary collecting duct. Evidence for involvement of the cystic fibrosis transmembrane conductance regulator. $J$ Clin Invest 95: 644-650.

IsMAILOV II, WAYDA A, Jovov MS, BEADIEV BK, FulleR CM, Didman JR, Koetzel M \& Benos DJ. 1996. Regulation of epithelial sodium channels by the cystic fibrosis transmembrane conductance regulator. $J$ Biol Chem 271: 4725-4732.

JENTSCH TJ. 1994. Structure and function of chloride channels. Jpn J Physiol 44: S1-S2.

Kizer NL, VAndorpe D, Lewis B, Bunting B, Russell J \& Stanton BA. 1995. Vasopressin and cAMP stimulate electrogenic chloride secretion in an IMCD cell line. Am J Physiol Renal Physiol 268: F854F861.

Koeppen BM \& Stanton BA. 1992. Sodium chloride transport: distal nephron. In: "The Kidney: physiology and pathophysiology" (DW SELDIN \& G GIEBISCH, eds.). 2nd ed. pp 2003-2039, Raven Press, New York.

Lehmann-Horn F \& Jurkat-Rott K. 1999. Voltagegated ion channels and hereditary disease. Physiol Rev 79(4): 1317-1372.

Letz B \& Korbmacher C. 1997. cAMP stimulates CFTR-like $\mathrm{Cl}$ channels and inhibits amiloridesensitive $\mathrm{Na}^{+}$channels in mouse CCD cells. Am J Physiol Cell Physiol 272: C657-C666.

Ling BN, Koкko KE \& Deaton DC. 1994. Prostaglandin $E_{2}$ activates clusters of apical $\mathrm{Cl}$ channels in principal cells via cyclic adenosine monophosphate-dependent pathway. J Clin Invest 93: 829-837.

LuKE RG. 1973. Natriuresis and chloruresis during hydropenia in the rat. Am J Physiol 224: 13-20.

Marvao P, de Jesus Ferreira MC, Bailly C, Paulais 
M, Bens M, Guinamard R, Moreau R, VanderWALli A \& TEUlON J. 1998. $\mathrm{Cl}^{-}$absorption across the thick ascending limb is not altered in cystic fibrosis mice. A role for a pseudo-CFTR $\mathrm{Cl}^{-}$channel. $J$ Clin Invest 102(11): 1986-1993.

McNicholas CM, Guggino WB, Schwiebert EM, Hebert SC, Giebisch G \& Egan ME. 1996. Sensitivity of a renal $K^{+}$channel (ROMK2) to the inhibitory sulfonylurea compound glibenclamide is enhanced by coexpresion with the ATP-binding cassette transporter cystic fibrosis transmembrane regulator. Proc Natl Acad Sci USA 93: 8083-8088.

Morales MM, Carroll TP, Morita T, Schwiebert EM, Devuyst O, Wilson PD, Lopes AG, StanTon B, Dietz HC, Cutting GR \& Guggino WB. 1996. Both the wild type and the functional isoform of CFTR are expressed in kidney. Am J Physiol Renal Physiol 270: F1038-F1048.

Morales MM, Capella MAM \& Lopes AG. 1999. Structure and function of the cystic fibrosis transmembrane conductance regulator. Braz J Med Biol Res 32(8): 1021-1028.

MORRIS AP. 1999. The regulation of epithelial cell cAMP and calcium-dependent chloride channels. Adv Pharmacol 46: 209-251.

Morris AP \& Frizzell RA. 1994. Vesicle targeting and ion secretion in epithelial cells: implications for cystic fibrosis. Ann Rev Physiol 56: 371-397.

Moyer BD, McCoy de, Lee B, Kizer N \& Stanton BA. 1995. Adenosine inhibits arginine vasopressinstimulated chloride secretion in a mouse IMCD cell line (mIMCD-K2). Am J Physiol Renal Physiol 269: F884-F891.

RIORDAN JR. 1993. The cystic fibrosis transmembrane conductance regulator. Ann Rev Physiol 55: 609630 .

Riordan JR, Rommens JM, Kerem B, Alon N, Rozmahel R, Grezelczak Z, Zielenski J, LoK S, Plavsic N, Chou J, Drumm ML, Iannuzzi MC, Collins FS \& Tsui L-C. 1989. Identification of the cystic fibrosis gene: cloning and characterization of complementary DNA. Science. 245: 1066-1073.

Rocha AS \& Kudo LH. 1990. Factors governing sodium and chloride transport across the inner medullarycollecting duct. Kidney Int 38: 654-667.

RoJAs CV. 1996. Ion channels and human genetic diseases. News Physiol Sci 11: 36-42.

Rommens JM, Iannuzzi MC, Kerem B, Drumm ML, Melmer G, Dean M, Rozmahel R, Cole JL, Kennedy D, Hidaka N, Zsiga M, Buckwald M, Riordam JR, Tsui L-C \& Collins FS. 1989. Identification of the cystic fibrosis gene: chromosome walking and jumping. Science 245: 1059-1065.

Rubera I, Tauc M, Verheecke-Mauze C, Bidet M, Poujeol C, Touret N, Cuiller B \& Poujeol P. 1999. Regulation of cAMP-dependent chloride channels in DC1 immortalized rabbit distal tubule cells in culture. Am J Physiol Renal Physiol 276: F104-F121.

Sasaki S, Uchida S, Kawasaki M, Adachi S \& Marumo F. 1994. ClC family in the kidney. Jpn J Physiol 44: S3-S8.

Schwiebert EM, Egan ME, Hwang T-H, Fulmer SB, Allen SS \& Guggino WB. 1995. CFTR regulates outwardly rectifying chloride channels through an autocrine mechanism involving ATP. Cell 81: 10631073.

Segal AS, Geibel J \& Boulpaep EL. 1993. A chloride channel in the basolateral membrane of rabbit proximal tubule. J Am Soc Nephrol 4: 879-881.

Stanton BA. 1989. Characterization of apical and basolateral membrane conductance of rat inner medullary collecting duct. Am J Physiol Renal Physiol 256: F862-F868.

Stenvinkle P, Huelte L, Alvan G, Hedman A, HultMAN E \& StrandviK B. 1991. Decreased renal clearance of sodium in cystic fibrosis. Acta Paediatr Scand 80: 194-198.

Strandvik B, Berg U, Kallner A \& Kusoffsky E. 1989. Effect on renal function on essential fatty acid supplementation in cystic fibrosis. J Pediatr 115: 242-250.

Stutts MJ, Canessa CM \& Olsen JC. 1995. CFTR as a cAMP-dependent regulator of sodium channels. Science 269: 847-850. 
Sullivan LP, Wallace DP \& GRantham JJ. 1998. Epithelial transport in polycystic kidney disease. Physiol Rev 78(4): 1165-1191.

TAuc M, Bidet M \& Poujeol P. 1996. Chloride currents activated by calcitonin and cAMP in primary cultures of rabbit distal convoluted tubule. J Memb Biol 150: 255-273.

Todd-Turla KM, Kusvai E, Náray-Fejes-Tóth A \& FEjes-Tóth G. 1996. CFTR expression in cortical collecting duct cells. Am J Physiol Renal Physiol 270: F237-F244.

Tsui L-C \& Buchwald M. 1991. Biochemical and molecular genetics of cystic fibrosis. In "Advances in Human Genetics" (H. HARRIS \& K. HirschHORN, eds.) 20: 153-266, Plenum, New York.
WANG W. 1999. Regulation of the ROMK channel: interaction of the ROMK with associate proteins. Am J Physiol Renal Physiol 277: F826-F831.

WILSON PD. 1997. Epithelial cells polarity and disease. Am J Physiol Renal Physiol 272: F434-F442.

Winter MC, Sheppard DN, Carson MR \& Welsh MJ. 1994. Effect of ATP concentration on CFTR $\mathrm{Cl}^{-}$ channels: a kinetic analysis of channel regulation. Biophys J 66: 1398-1403.

Woodland C, Blowey D, Ito S, Spino M \& Koren G. 1998. Hypothetical framework for enhanced renal tubular secretion of drugs in cystic fibrosis. Med Hypothesis 51(6): 489-491. 